\title{
The Effect of Psychological First Aid in Improving Multidimentional Pain Sympotems and the Way of Coping with Stress on Women Suffering M.S
}

\author{
$\underline{\text { Parviz Karimisani }}^{1}$, Sima Mahdilou ${ }^{2}$, Sara Mansouri $^{3}$, Zahra Sajjadizadeh ${ }^{4}$ \\ 1- Assistant of professor, Department of psychology, Islamic Azad University of Shabestar, Tabriz, Iran. \\ ORCID: 0000-0002-1982-2199Ｅ-mail: karimisani.counsel@gmail.com \\ 2- MA in counseling and guidance, Islamic Azad University of Shabestar, Tabriz, Iran. ORCID: 0000-0001- \\ 9851-0997 \\ 3- MA in counseling and guidance, Islamic Azad University of Tabriz, Iran. ORCID: 0000-0002-6833-6462 \\ 4- MA in general psychology, Payam Nour University, Mahabad, Iran. ORCID: 0000-0001-8412-717X
}

Received: 03/06/2018

Accepted: 06/11/2018

\begin{abstract}
Introduction: MS patients suffering from MS because of their stress and pain require different assistance during physical and mental therapy.

Aim: The aim of the current study was to determine the effectiveness of education of psychological first aid in improving multidimensional pain inventory and the style of coping inventory for stressful situations on women suffering M.S.

Method: The design of this study a semi-experimental design was used for pre-test and posttest with experimental and control groups which 30 women suffering M.S were selected by available sampling. Then they were randomly assigned to treatment $(n=15)$ and control group $(n=15)$. Members of two groups completed the Aggression Questionnaire Multidimensional Pain Inventory (MPI) and Coping Inventory for Stressful Situations (CISS) in two phases of pre-test and post-test. Treatment consisted of education of psychological first aid over eight weeks. Analysis of Covariance was used for analyzing the data.
\end{abstract}

Results: Results of hypotheses showed that training of psychological first aid was efficient and useful in improving multidimensional pain symptoms $(\mathrm{P}<0 / 05)$. and coping style for stressful $(\mathrm{P}<0 / 01)$ situations in women suffering M.S.

Conclusion: Training of psychological first aid can improve multidimensional pain symptoms and coping style for stressful situations in women suffering M.S.

Keywords: Psychological First Aid, Multidimensional Pain, Coping with Stress.

How to cite this article : Karimisani P, Mahdilou S, Mansouri S, Sajjadizadeh Z. The Effect of Psychological First Aid in Improving Multidimentional Pain Sympotems and the Way of Coping with Stress on Women Suffering M.S. Shenakht Journal of Psychology and Psychiatry. 2018; 5 (4): 87-98 .URL :http://shenakht.muk.ac.ir/article-1-531-fa.pdf

Copyright $\odot 2018$ the Author (s). Published by Kurdistan University of Medical Sciences. This is an open access article distributed under the terms of the Creative Commons Attribution-Non Commercial License 4.0 (CCBY-NC), where it is permissible to download, share, remix, transform, and buildup the work provided it is properly cited. The work cannot be used commercially without permission from the journal. 


\title{
تأثير آموزش كمكهاى روانشناختى اوليه بر بهبود علائم حند وجهى درد و سبك

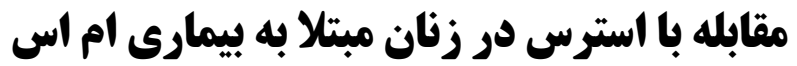

\author{
يرويز كريمى ثانى'، سيده سيما مهدى لو'، سارا منصورى'، سيده زهرا سجادى زاده \\ ا. دكتراى مشاوره، گروه روان شناسى، دانشكاه آزاد اسلامى، واحد شبستر، تبريز، ايران. ايميل: garimisani.counsel@ gmail.com

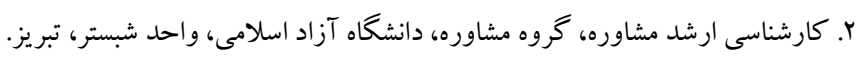

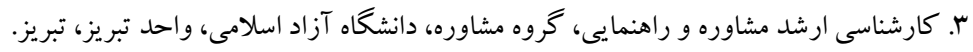

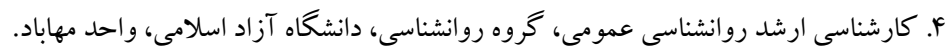

مقدمه: زنان بيمار مبتلا به بيمارى ام اس به دليل وجود استرس و درد نياز به كمكك هاى مختلفى در زمان درمان جسمى و روانى دارند. هدف: يثزوهش حاضر براى تعيين اثربخشى آموزش كمككهاى روانشناختى اوليه بر بهبود علائم جندوجهى درد و سبككهاى مقابله با شر ايط يراسترس در زنان مبتلا به اماس انجام شد. روش: طرح اين بزووهش از نوع نيمه آزمايشى يش آزمون و بس آزمون با گروه كنترل بود كه در آن .ب زن مبتلا به بيمارى ام اس

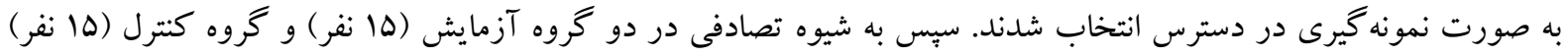

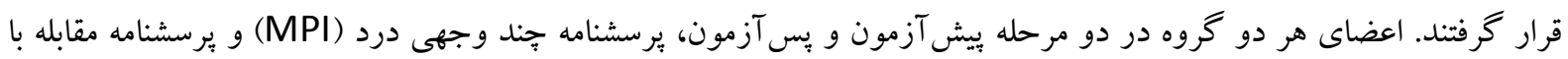

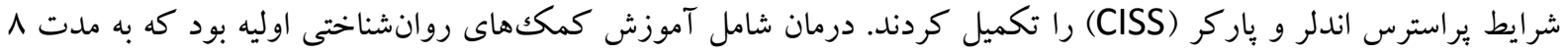
جلسه بر گزار شد. براى تجزيهوتحليل دادها از تحليل كواريانس استفاده شد. يافتها: نتايج حاصل از آزمون فرضيهها نشان داد كه آموزش كمككهاى روانشناختى اوليه بر بهبود علائم جندوجهى درد

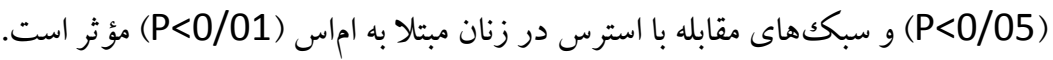
نتيجه كيرى: با استفاده از آموزش كمككهاى روانشناختى اوليه مىتوان علائم جندوجهى درد و سبككهاى مقابله با استرس در زنان مبتلا به ام|س را بهبود بخشيد. كليدوازهها: كمككهاى روانشناختى اوليه، تجندوجهى درد، سبككهاى مقابله با استرس 

عوامل ديخرى رخ مى دهد. استفاده از داروها گزينه مقدمه اول درمان دردهاى نوروياتيكك محسوب مى شود. درد ثانويه در ام اس نسبتاً شايع است زيرا ضعف، اسباستيسيته و ديخر علائم اماس مىتواند روى تمام سيستم عضلانى - اسكلتى تأثير بخذارد. زمانى كه مشكلى بيش مى آيد، گردن، قسمت بايين كمر و زانوها مظنونين اصلى به شمار مىروند. رابطه بين استرس و

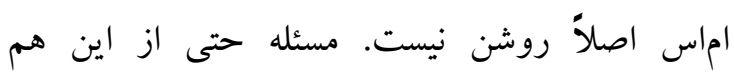
يبيجيدهتر است، به صورتى كه تحقيق در اين زمينه آدم

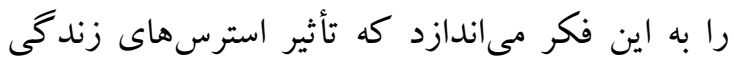
شخصى تا حد زيادى به قدرت تطبيقيذيرى فرد و همينطور توانايىهاى او و گروه يشتيبانش در حل

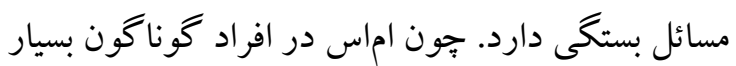
متفاوت است و هيج دو نفرى قدرت تطبيق و جارهانديشى يكسان ندارد. يككراه خوب براى مترى مقابله با اين نوع احساسات و كاستن از استرس اين است كه زمانى را در منطقهى عارى از اماس سبرى كنيد. يكك قلمرو جادويى نيست، ولى جاى خوبى است. اين مكان جايى است كه دست اماستان به شما نمىرسد. (لطيفى .(1)q.

متغير ديخر سبك مقابلهاى است كه عبارت است از

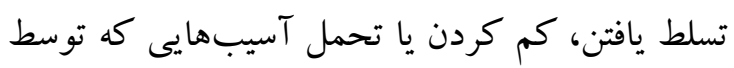
استرس ايجاد مىشود (اندرو پاركر •(199)، بر اساس تحقيقى جهت بررسى فر آيند مقابله عمومى، افراد را برحسب سه نوع اساس سبكك مقابلهاى متمايز

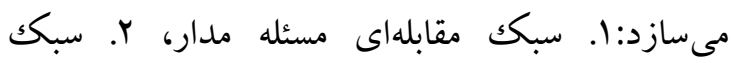
مقابلهاى هيجان مدار و سّ. سبكك مقابلهاى اجتنابى

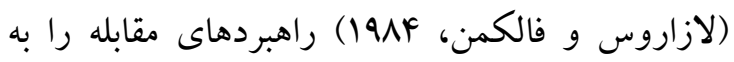
عنوان مجموعهاى از ياسخهاى شناختى كه هدفشان به وله حداقل رساندن، فشارهاى موقعيت استرسزا است تعريف كردهاند. گرجهه راهبردهاى مقابله فعاليتهاى بسيارى را شامل مىشوند، اكثر آنها مبين تلاش براى

درد تجربهاى ذهنى و يديده ادراكى بيجِيدهاى است و به همين دليل توصيف آن مشكل است. ذهنى بودن درد هم در دركك متخصصان از آن و هم در تلاشهايى كه براى درمان آن به عمل مى آورند، محدوديتهاى

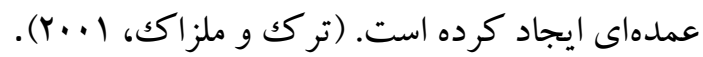
درد مزمن جيزى بيش از يكك علامت جسمى است. استمرار درد و مزمن شدن آن باعث به وجود آمدن مشكلات بسيارى مى گردد. از جمله تضعيف روحيه، اختلالات عاطفى، دلمشغولى مداوم با درد، محدوديت فعاليتهاى فردى و اجتماعى و شغلى، افزايش استفاده

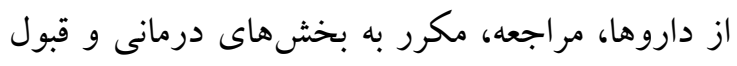

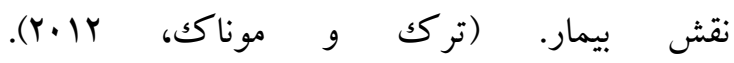
بحث درد مزمن در بيماران اماس ويامدهاى مختلفى به دنبال دارد، اماس مىتواند باعث بروز تغييرات حسى لمى

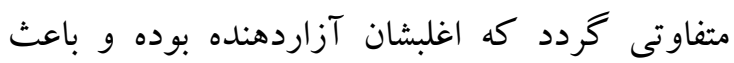
ناراحتى است، اما خطرناكى نيست؛ به عبارت ديخر ممكن است از وجودشان بيزار باشيم ولى دليل شاخصى براى بيشرفت بيمارى به حساب نمى آيد و

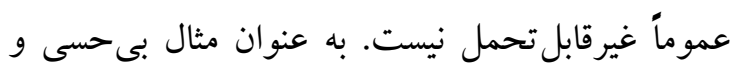
احساس گز گز در اندام ها خيلى شايع است. از ديد كاه

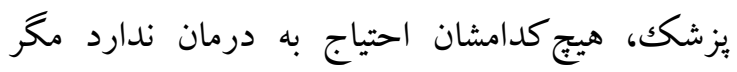
اينكه موجب زحمت فرد شود؛ كه با يكك مدت كوتاه

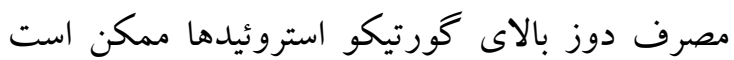
كمك كننده باشد (لطيفى .qr) (1). درد ناشى از اماس را مىتوان به دو نوع اصلى زير

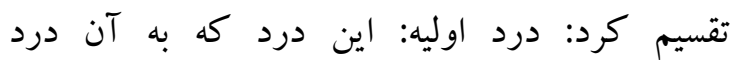

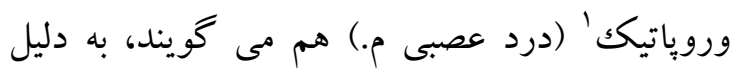
التهاب و دميليناسيون در مسير اعصاب حسى مغز و طناب نخاعى به وجود مى آيد. منشاء عصبى دارد. درد ثانويه: اين نوع درد به صورت غيرمستقيم به دليل 


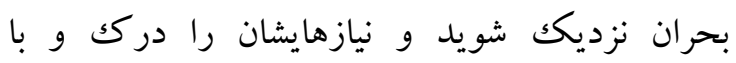
اطلاعات و حمايتهاى عملى با آنها ارتباط برقرار

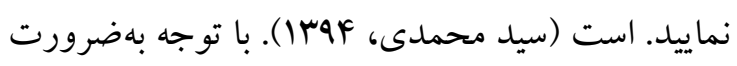

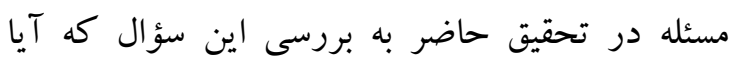
آموزش كمككهاى روانشناختى اوليه بر بهبود علائم جندوجهى درد و سبكك مقابله با استرس در بيماران اماس زن تأثير دارد؟ يرداخته خواهد شد.

روش طرح بثزوهش از نوع نيمه آزمايشى (با طرح بيش آزمون

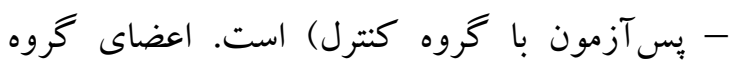

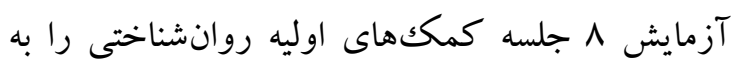

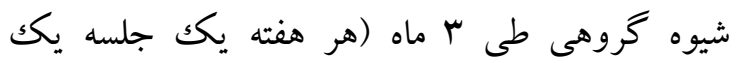
ساعتى) دريافت نمودند، در حالى كه گروه كنترل هيج نوع درمانى را دريافت نكردند. يس از اتمام جلسات

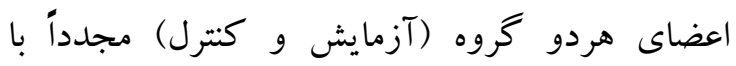

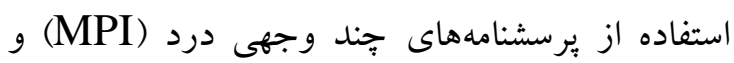
مقابله با شرايط يراسترس اندلر و پياركر (CISS)، مورد ارزيابى قرار گرفتند. جامعه آمارى بُزوهش شامل كليه زنان مبتلا به بيمارى ام اس كه به انجمن اماس آذربايجان شرقى مراجعه كردند است. نمونه مورد

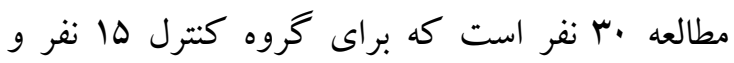
كروه آزمايش ها نفر مىباشند. روش نمونه گيرى در اين يُوهش، روش در دسترس بودن، اما جايخزينى نمونهها در گرووهاى آزمايش و كنترل با شيوه تصادفى رونى

ابز ار ابزار يُزوهش عبارت بودند ازئ برسشنامه جِندوجهى درد وست هيون- ييل و يرسشنامه مقابله با شرايط

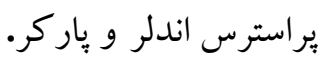

بهبود يكك موقعيت دشوار مثل طراحى نقشه و اقدام

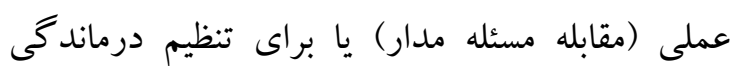

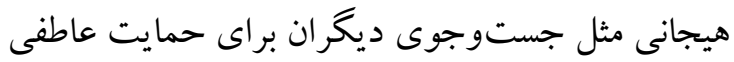
با كاهش شدت دشوارى موقعيت از نظر شناختى (مقابله هيجان مدار ) هستند. استرس مى تو اند بهزيستى و

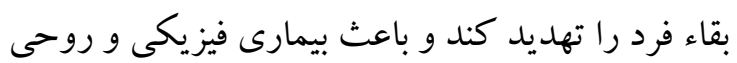

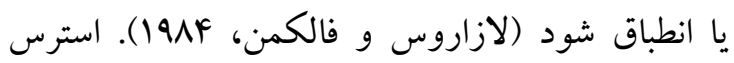
خيلى زياد يا خيلى كم منجر به تباهى عملكرد مى شود.

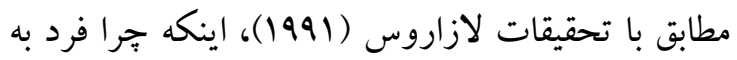
يكك استرس منفى واكنش نشان مىدهد به عوامل زيادى از جمله واكنش فردى استرس آور بستخى دارد. ادراكك استرس به حدود فشارها و ميز ان منابعى كه افراد براى مقابله با آنها در اختيار داشته وابسته است (لازاروس، (1991) و ولفولك (19AV) عنوان كردند كه استرس يكك تجربه شناختى است كه با ادراكك فرد از رابطه خود و محيط ارتباط دارد. كمككهاى اوليه روانشناختى در مورد افرادى كه دجهار

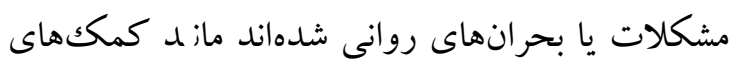
اوليه در حوادث اهميت ويزهاى دارند؛ در مورد فردى كه دجار اختلالات روانى ماند اضطراب و استرس يا بحرانهاى ناشى از بيمارىهاى غيرقابل علاج و يا حالتهاى توهمى مىشود، نيز بايد اقدامات اوليهى

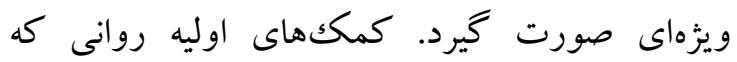
مىتواند در اين شرايط به افراد كمكك كند شامل آرامش بخشى، هم دردى و همدلى، قضاوت و و سرزنش نكردن فرد و انخيزه بخشى براى رفع مشكل دردي است (سيد محمدى، سوبr). كمككهاى اوليه روانشناختى واكنش و پِاسخ حمايتى

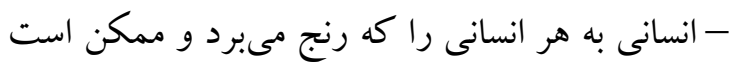

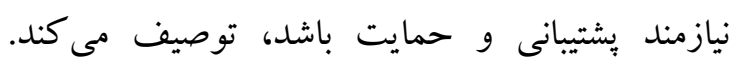
اصول عملى كمككهاى اوليه روانشناختى: نغاه كردن، گوش دادن و برقرارى ارتباط هستند. به افراد دجار 
برخورد فعال با مسئله در جهت مديريت و حل آن. r. -

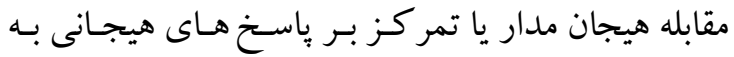
مسئله... بـ- مقابله اجتنابى يا فرار از مسئله. مقياس مقابلهـ

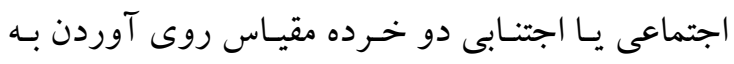

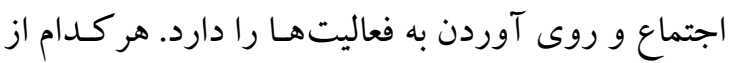
شيوههاى كنار آمدن يكك مقيـاس جدا گانهه بـا 19 مـاده دارد و مجموع نمرات هـر يـكك از مقيـاسهـا جداكانهـ محاسبه مى شـود و فاقـد نمـره كلـى اسـت. البتـه خـرده مقياس كنار آمدن اجتنابى يعنى روى آوردن به اجتمـاع و روى آوردن به فعاليتهـا هر كـدام ^ مـاده مسىباشـند. هر كدام از مادههـاى برسشـنامه شـيوههـاى كنـار آمــدن

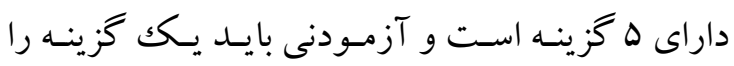

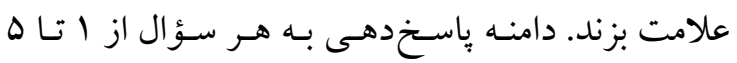

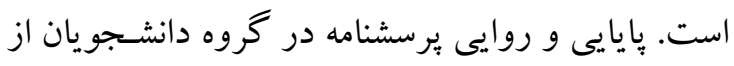
آلفاى كرونباخ استفاده شده است كـه در مقابله مسـئله

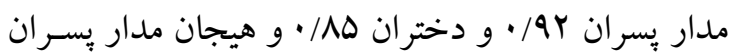

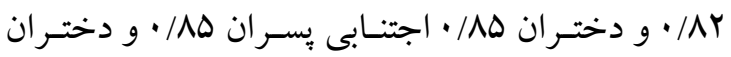

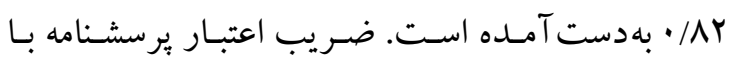
موقعيتهاى استرسزا از طريق آلفاى كرونباخ يزوهش قريشى در سطح بالايى (سM|N/ •) به دست آمده است. روايى برسشنامه نيز طلى تحقيقـاتى كـه در ايـران انجـام

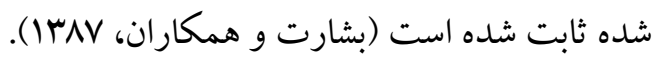
يروتكل هر جلسه درمان بر اساس منابع مستخرج از يروزه كمككهاى اوليه در استراليا اين گونه تدوين

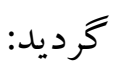

برسشنامه جندوجهى درد وست هيون- ييل: كرنز و

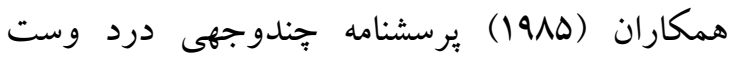
هيون- ييل را بر مبناى نظريه شناختى رفتارى درد

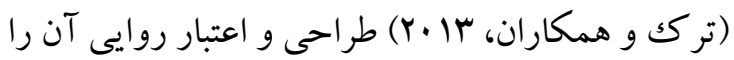
در ميان · rا بيمار مبتلا به درد مزمن مورد تائيد قرار دادند. اين برسشنامه از سه بخش مستقل از يكديخر مئر تشكيل شده است: بخش اول شامل ·r عبارت و از

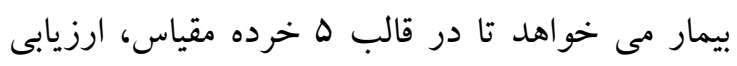

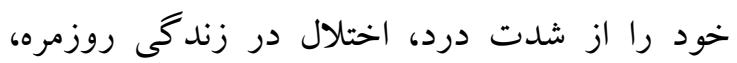
ههارت بر زندگىى، اختلال عاطفى و حمايت گزارش كند. بخش دوم داراى If أسبارت در قالب سه خرده

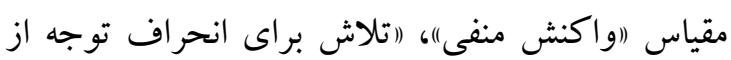

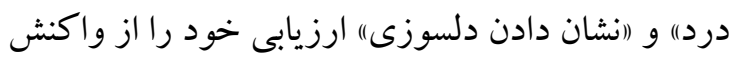
همسر يا ساير افراد صاحب نقش در زندگىاش، نسبت به دردى كه از آن رنج مىبرد درجهبندى كند. بخش يخ سوم داراى \1 اعبارت و در قالب جهار خرده مقياس، فراوانى فعاليت بيمار را در امور (اخانهدارى)، (امور مربوط به تعمير و نخهدارى وسايل منزل)، (افعاليتهاى اجتماعى" و (انجام فعاليتهاى بيرون از منزل) ارزيابى

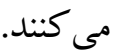
يرسشنامه مقابلـه بـا شـرايط يراسترس انسلـر و يـاركو (CISSS)

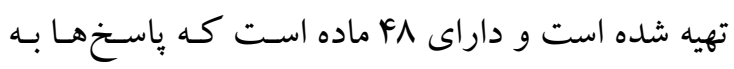
روش ليكرت از هر زز (1) تا هميشـهـ (ه) مشـخص شـــه

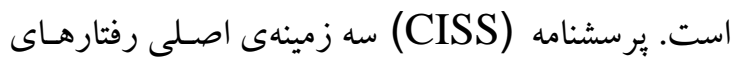

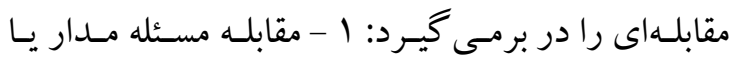

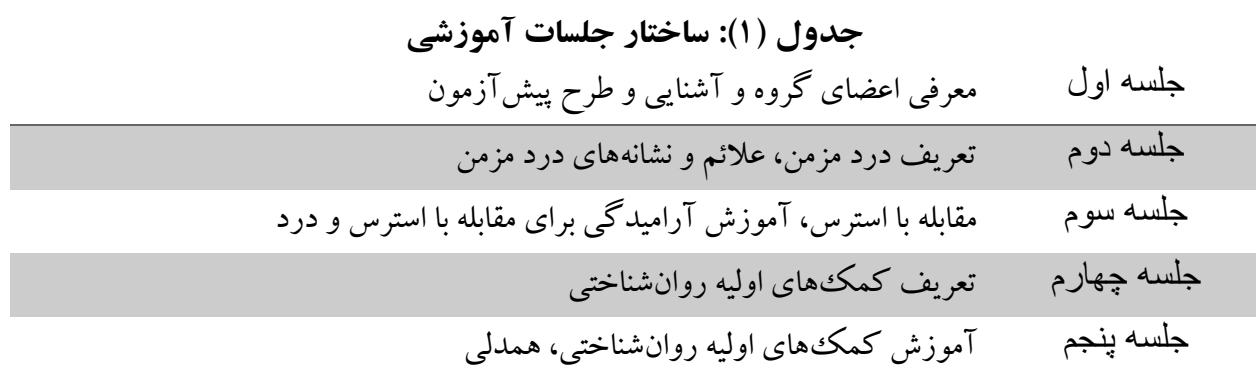




$$
\begin{aligned}
& \text { جلسه ششم آموزش كمككهاى اوليه روانشناختى، قضاوت و سرزنش نكردن فرد }
\end{aligned}
$$

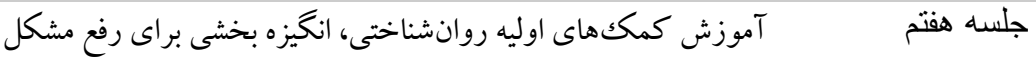

$$
\begin{aligned}
& \text { جلسه هشتم اختتام گروه و جمعبندى، اجراى بس آزمون. }
\end{aligned}
$$

مدرك كارشناسى و · ا نفر مدرك كارشناسى ارشد داشتند. سن آنها بين هץ-F.F سالكى بود. بهمنظور ارائه

تصويرى روشن از يافتهاى يزٔوهش، در جدول (1) يافته هاى توصيفى متغير هاى اختلال در عملكرد روزانه، شدت درد، حمايت اجتماعى، مهار بر زندكى، بريشانى هيجانى، پِاسخ منفى، دلسوزى و انحراف توجه به تفكيك كروه كنترل و آزمايش در بيش آزمون و

$$
\text { يس آزمون ارائهده است. }
$$

به منظور تجزيه و تحليل داده ها، از آمار توصيفى (ميانه، ميانگين، انحراف استاندارد) و آمار استنباطى لري (تحليل كواريانس، براى آزمون فرضيههاى اول، دوم و سوم) استفاده شد. لازم به ياد آورى است كه داده ها با استفاده از نرم افزار 20 SPSS مورد تجزيه و تحليل قرار كرفت.

نتايج

در مورد خصوصيات دموكرافيك، ·ب نفر زن مبتلا به اماس بودند كه تمامى آنها متأهل بودند و ·r نفر

جدول ( (1): يافتهاى توصيفى مربوط به متغيرهاى اختلال در عملكرد روزانه، شدت درد، حمايت اجتماعى، مهار بر زندكى،

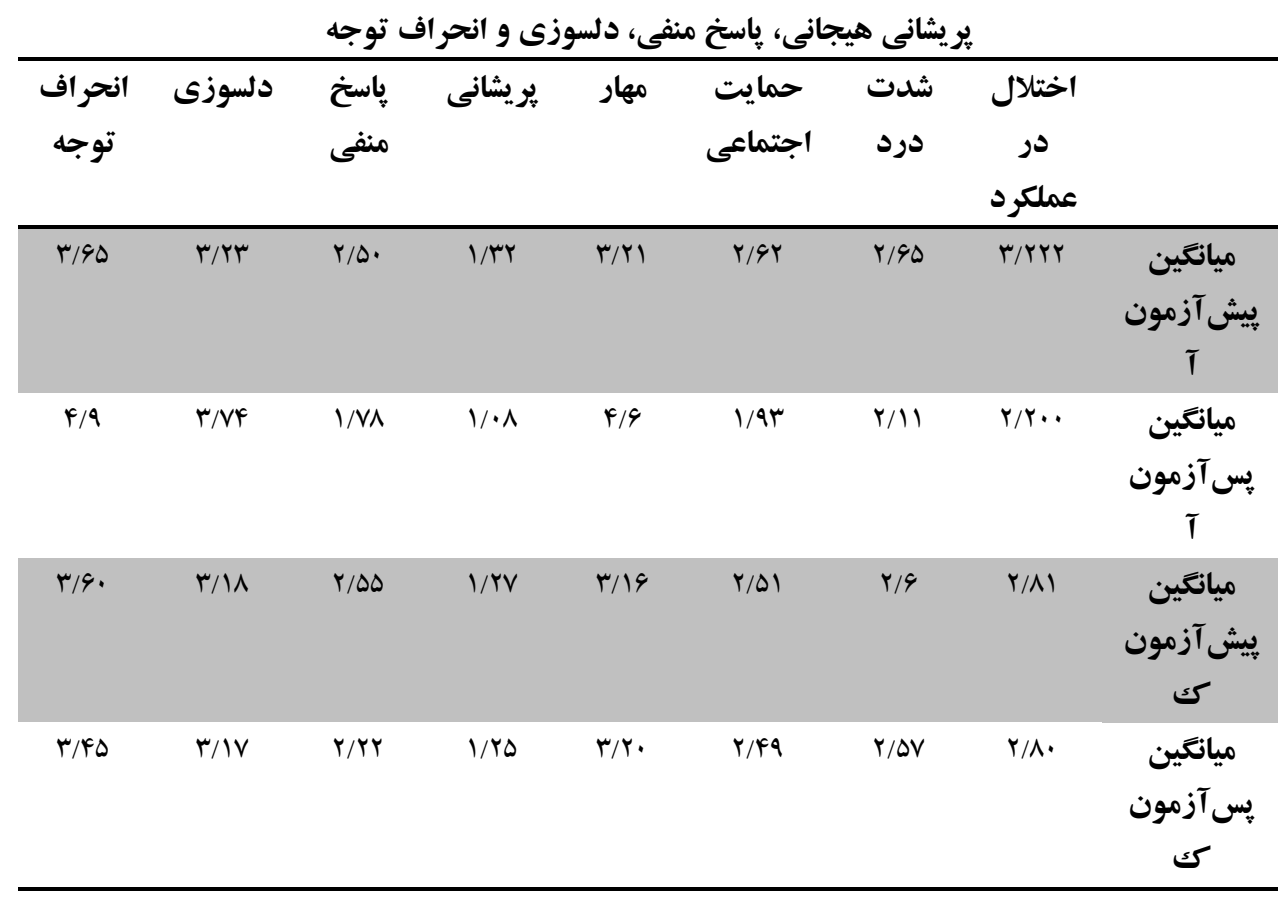

در جدول (Y) يافته هاى توصيفى متغيرهاى مقابله مسئله مدار، مقابله هيجان مدار و مقابله اجتنابى به تفكيك
در جدول شماره (1) نتايج بهدست آمله نشان مىدهند كه اختلاف جندانى در ميانخين نمرههاى گروههاى كنترل و آزمايش در بيش آزمون و جود ندارد. 
كروه كنترل و آزمايش در ييش آزمون و بس آزمون

جدول (ץ): يافته هاى توصيفى مربوط به متغيرهاى مقابله مسئله مدار، مقابله هيجان مدار و مقابله اجتنابى

\begin{tabular}{|c|c|c|c|}
\hline مقابله اجتناب مدار & مقابله هيجان مدار & مقابله مسئله مدار & \\
\hline$F \cdot / V \Delta$ & $\mathrm{Fq} / \mathrm{VF}$ & k4 & يشيش آيانمين \\
\hline$\Gamma^{M / \Delta 9}$ & $r \cdot / r r$ & $\Delta \cdot / r$ & يس ميانگين \\
\hline$F \mid / A$. & $<q / \wedge q$ & $49 / 49$ & بيش آزمون كيانكين \\
\hline$|F| / F \mid$ & 0.190 & $F G / F V$ & يس ميآزمون كى \\
\hline
\end{tabular}

باسخ منفى، دلسوزى و انحر اف توجه در بيش آزمـون و

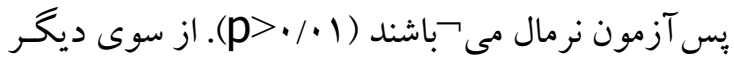
توزيع نمرات مقابله مسئله مــار، مقابله هيجـان مـدار و مقابله اجتناب مدار در ييش آزمون و پِس آزمـون نرمـال

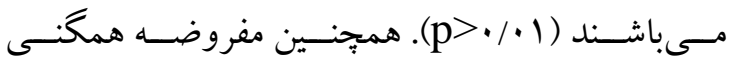

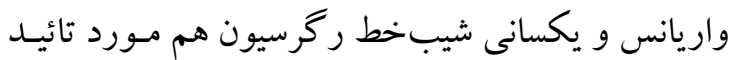
قرار كرفت. فرضيه اول: آموزش كمككهاى روانشـناختى اوليـهـ بـر بهبود علائم جندوجهى درد مؤلفه هاى آن در زنان مبتلا

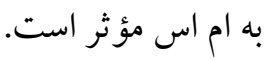

در جدول شماره (Y) نتايج بهدست آمده نشان مىدهنـد كه اختلاف جندانى در ميـانگين نمـرهـاى گـروههـاى كنترل و آزمايش در ييش آزمون وجود ندارد. به منظور بررسى صحت مفروضه نرمال بودن متغيرهـا از آزمون كولمو گروف - اسميرنف استفاده شـد، سطوح معنى دارى بـهدست آمـده در جـدول شـماره (Y) نشـان مى دهند كه توزيع نمرات اختلال در عملكـرد روزانه،

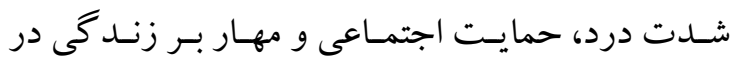

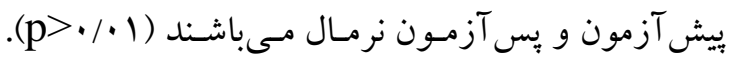
هم:جنين سطوح معنى دارى بهدست آمده جـدول شـماره

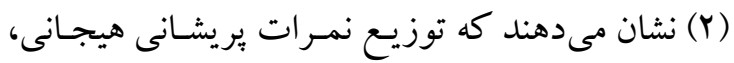

\begin{tabular}{|c|c|c|c|c|c|}
\hline سطح معنى دارى & $\mathbf{F}$ & مياتكين مجذورات & آزادى درجه & مجذوروات & منبع \\
\hline$\cdot / \cdot F$ & $1 \cdot / r \cdots$ & 1./ & 1 & $1 \cdot /$ rar & كروه (شدت درد) \\
\hline.$/ .4$ & $F / 9 \Delta \Delta$ & Y/YFE & 1 & T/YFG & كروه (حمايت) \\
\hline$\cdot / M r$ & $r \Lambda / V \cdot$ & YF/VqV & 1 & YF/VqV & ي ي بيش آزمون \\
\hline.$/ \cdot 1 f$ & $9 / 191$ & $\Delta / Q \Delta F$ & 1 & $\Delta / Q \Delta F$ & كروه (عملكرد) \\
\hline
\end{tabular}

بهبود اختلال در عملكرد روزانه، شدت درد و بهبود حمايت اجتماعى زنان مبتلابه اماس مؤثر است.
با توجه به نتايج بلدست آمده از جدول (r) مىتوان

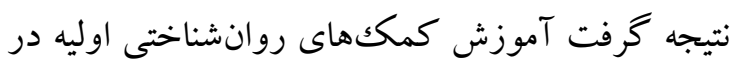


اوليه) است. همجنين ه ه درصد تغييرات نمرات كروهها در متغير شدت درد (تفاوت كروهها در يس آزمون) ناشى از اجراى متغير مستقل (آموزش كمككحهاى روانحشناختى اوليه) است.
همجنين مقدار مجذور ايتا نشان دهنده اين است كه •ه درصد تغييرات نمرات گروهها در متغير اختلال در عملكرد روزانه (تفاوت گروهها در يس آزمون) ناشى از اجراى متغير مستقل (آموزش كمككهاى روانشناختى

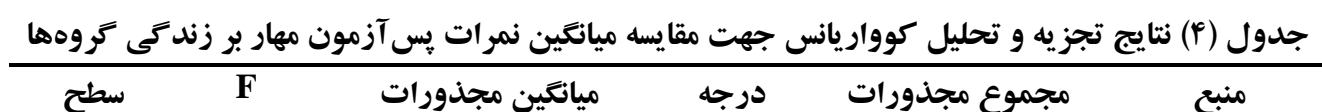

\begin{tabular}{|c|c|c|c|c|c|}
\hline معنى دارى & & & زادى & & \\
\hline.$/ \cdot 1 f$ & $9 / 949$ & r/MAF & 1 & r/IAF & 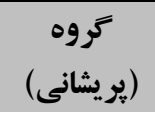 \\
\hline$\cdot / \cdot T_{F}$ & r/OrG & $1 / \mu F$ & 1 & I/TF. & $\begin{array}{c}\text { كروه (ياسخ منفى) } \\
\text { منفى }\end{array}$ \\
\hline .1 .90 & $9 / 901$ & 91994 & 1 & $9 / 994$ & بيش آزمون \\
\hline.$/ \cdot 1$ & IF/FYq & IT/AYF & 1 & Ir/AYF & كروه (مهار) \\
\hline
\end{tabular}

مقدار مجذور ايتا نشان دهنده اين اسـت كـه FF درصـد تغيـرات نمـرات گـروههـا در متغيـر حمايست اجتمـاعى (تفاوت كروه ها در يس آزمون) ناشسى از اجـراى متغيـر مستقل (آموزش كمككهاى روانشناختى اوليه) است .
با توجه به نتايج به دست آمده از جدول (F) تفـاوت بـين كروه ها در سطح معنادارى هو درصهـ اطمينـان معنـادار

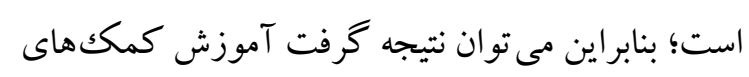

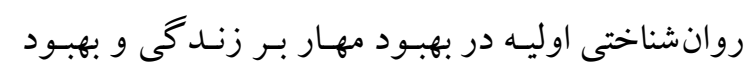
يريشانى هيجانى زنان مبتلا به ام اس مؤثر است. همجينين

\begin{tabular}{|c|c|c|c|c|c|}
\hline سطح معنى & $\mathbf{F}$ & مجذانگين & درجه آزادى & مجذموع & منبع \\
\hline$\cdot \%$ & $\mathrm{Fr} / \mathrm{QAY}$ & HY/lar & r & GF/TAG & مدل اصلاح شده \\
\hline$\cdot \cdots \wedge$ & T/YVY & $\Delta / V F \Lambda$ & 1 & $\Delta / V F \Lambda$ & $\begin{array}{c}\text { كروه (انحر افه) } \\
\text { توجه }\end{array}$ \\
\hline $.1 .9 \mathrm{~V}$ & Vq/gFf & $\Delta \Lambda / \Gamma)$ & 1 & $\Delta \Lambda / \Gamma I I$ & يِش آزمون \\
\hline.$/ \cdot k r$ & $r / F V F$ & T/DFY & 1 & Y/DFY & گروه (دلسوزى) \\
\hline
\end{tabular}

نمرات گروهها در متغير دلسوزى (تفاوت گروهها در

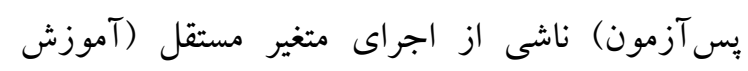

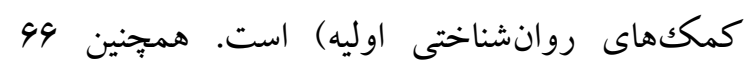
درصد تغييرات نمرات گروهها در متغير انحراف توجه

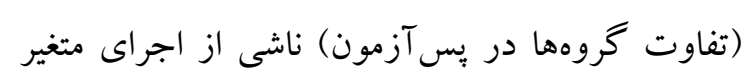

با توجه به نتايج بهدست آمده از جدول (ه) تفاوت بين كروهها در سطح معنادارى هو درصد اطمينان معنادار

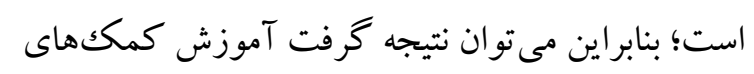

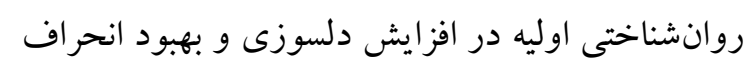
توجه زنان مبتلا به اماس مؤثر است. همجينين مقدار

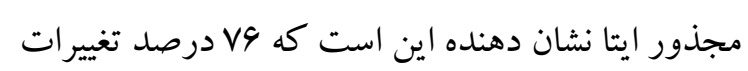


فرضيه دوم: آموزش كمككهاى روانشناختى اوليه بر مستقل (آموزش كمككحهاى روانحشناختى اوليه) سبك هاى مقابله با استرس (مسئله مدار، هيجان مدار و

اجتنابى) در زنان مبتلا به اماس مؤثر است.

\begin{tabular}{|c|c|c|c|c|c|}
\hline دعنى & $\mathbf{F}$ & ميانكين مجذورات & درادى & مجموع مجذورات & منبع \\
\hline$\cdot / \cdots$ & $r 9 / 991$ & $r \Delta \cdot / \wedge 9 \Lambda$ & 1 & $r \Delta \cdot / \wedge q \Lambda$ & كروه (هيجان مدار) \\
\hline.$/ .1$ & $10 / 4 \cdot 9$ & $r \cdot . / 990$ & 1 & $r \cdots / 990$ & كروه (اجتناب) \\
\hline$\cdot / I \mathrm{rA}$ & Ir/WVA & $90 \cdot /$ AFD & 1 & $90 \cdot / A F \Delta$ & بيش آزمون \\
\hline$\cdot \ldots$ & N/AFV & $৭ \Delta ৭ / ৭ 99$ & 1 & $৭ \diamond ৭ / ৭ ৭ 9$ & كروه (مسئله مدار) \\
\hline
\end{tabular}

جند وجهى درد در زنان مبتلا به اماس مؤثر بوده است.

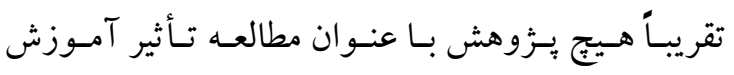
كمـككهــاى روانشــناختى اوليـهـ در بهبــود علائسما جندوجهى درد در زنان مبتلا بـه اماس صورت نكخرفته است. صلايانى و همكاران (99 I) در ئزوهشى نشـان

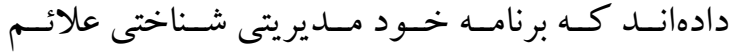
جندوجهى درد در زنـان مبـتلا بـه درد مـزمن را بـهـور معنى دارى كاهش داده است كه با نتايج بثزوهش حاضر

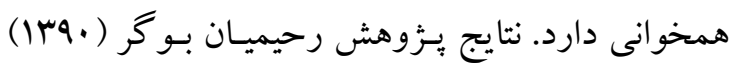

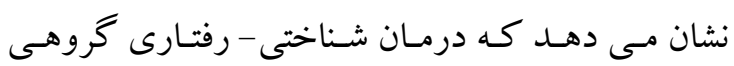
باعث كاهش علائم جندوجهى درد در بيمار ان مبـتلا بـهـ

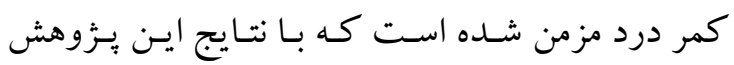

در تبيين اثربخشى آموزش كمككهاى روانشناختى اوليه بر كاهش علائم جندوجهى درد در زنان مبتلا به به بهري اماس مى توان به موارد زير اشاره كرد: الف (تجربه درد به تنهايى عامل اصلى ايجاد علائم جندوجهى درد در

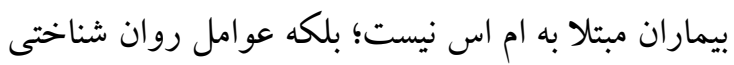

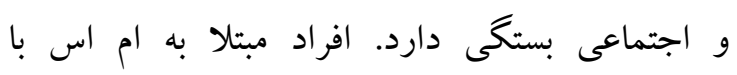
رويدادهاى استرس آور از جمله تحمل درد مواجه مى بـ شوند كه اين شرايط مىتواند آثار منفى و زيان بارى
با توجه به نتايج به دست آمده از جدول (9) تفـاوت بين كروه ها در سطح معنادارى 99 درصـد اطمينـان معنـادار است؛ بنابراين مى توان نتيجه كرفت آموزش كمككهاى دمادي روانشناختى اوليه در افزايش مقابله مسئله مدار، كاهش بـ حالت هيجان مدار و اجتنابى زنـان مبـتلا بـه اماس مـؤثر است. همجيجين مقدار مجذور ايتا نشان دهنده ايـن اسـت كه \ها درصد تغييرات نمرات گروه هـا در متغير مقابله مسئله مدار (تفاوت گحروههـا در بـس آزمـون) ناشى از اجراى متغير مستقل (آموزش كمككهـاى روانشـناختى

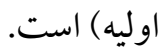

\section{نتايج}

نتايج بهدست آمده در بررسى فرضسيه اول نشـان داد كـه آموزش كمككهاى روانشناختى اوليه بـر بهبـود خـرده مقياس هاى اختلال در عملكرد روزانه، شدت درد، مهار بر زندگى و يريشانى هيجانى، حمايت اجتمـاعى، بِاسـخ منفى، دلسوزى و انحراف توجـه در علائسم جنـدوجهى درد در زنان مبـتلا بـه اماس مـؤثر بـوده اسـت. ولى در

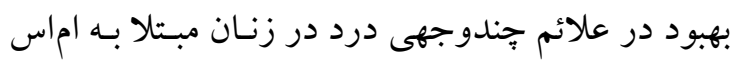

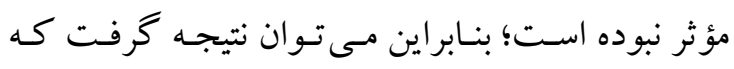
آموزش كمككهاى روانشناختى اوليه بـر بهبــود علائسم 
مقابلهاى مسئله مدار در بيماران مبتلا به اماس مىتوان

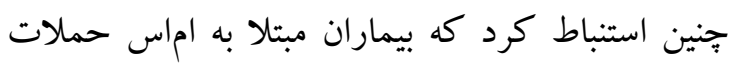
مكررى رادر طى بيمارى خود تجربه مى كنند و شرايط جسمى آنها كاملاً تحـت اختيارشان نيست، البته ممكن

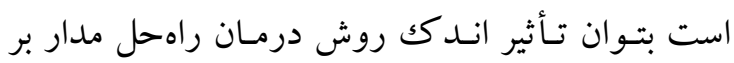
احساس انسجام آنها را بـه همسين علـت مـرتبط دانست، زيرا اين شرايط بهراحتى مىتو اند ديد آنها را

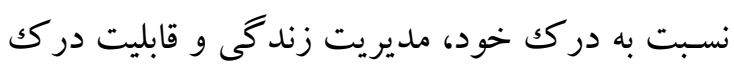

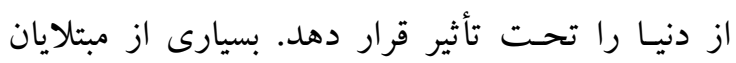
آيندهاى را بـراى خـود متصور نيستند و نغاه مثبتى به دهيه

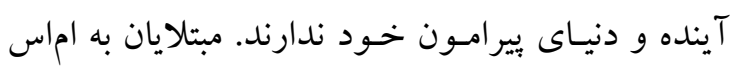
از نرخ بـالاى مشـكلات روانسى رنـج مىبرند و ميزان بالايى از افسردگى و نسبت به افراد مبـتلا بـه ساير مئر

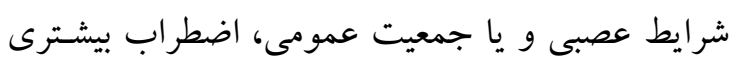
را تجربه مى كنند و اين متغيرها و متغيرهـاى ديخر

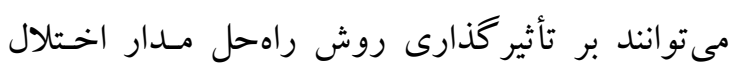
ايجـاد كنند؛ بنابراين آموزش كمككهاى روانشناختى اوليه بر سبك مقابلهاى مسئله مدار استرس مؤثر واقع

نتايج بهدست آمده در فرضيه دوم همبِنين نشان داد كه آموزش كمككهاى روانشناختى اوليه بر كاهش مقابله اجتناب مدار در زنان مبتلا به اماس تأثير دارد. همبحنين نتايج به دست آمده در فرضيه دوم نشان داد كه آموزش كمككهاى روانشناختى اوليه بر كاهش مقابله هيجان مدار در زنان مبتلا به اماس تأثير دارد. افسرى

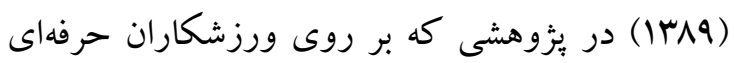

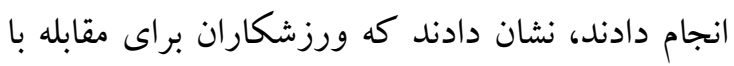

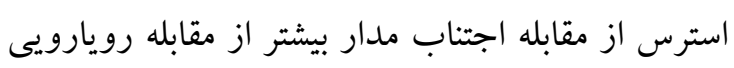

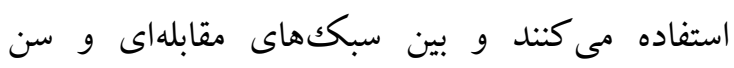
ورزشكاران تفاوت معنىدارى وجود دارد. بشارت و همكاران (IrNV نشان دادند كه سبك مقابله هيجان مدار مثبت با افزايش بهزيستى روانشناختى و كاهش
ازنظر روانشناختى داشته باشد و غير قابل تحمل بودن آن، زمينه خشم، برخاشخرى و بـىخوابى روان را ايجاد مىنمايد. آموزش كمككهاى روانشناختى اوليه باعث مىشود كه از يككسو افكار مثبت جايگزين افكار منفى

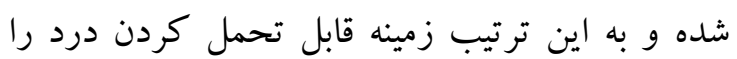
فراهم سازد. ب) تفكرات ناكارآمد، تفسير غير انطباقى از درد، تحريفهاى شناختى راجع به درد نظير فاجعه سازى درد، تعميم دهى افراطى و ترس از انجام فعاليتها و اجتنابهاى شناختى -رفتارى مرتبط با لـا شرايطى كه احتمال درد مىرود، استفاده از راهبردهاى مقابلهاى منفى و احساس عدم كنترل بر درد عواملى هستند كه بيش از تجربه صرف درد منجر به احساس

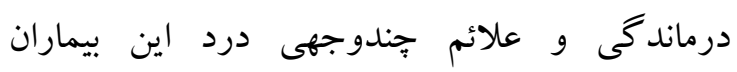
مى گردند كه همه اين موارد آماج درمان شناختى لمانى رفتارى هستند. ج) كاهش توانايى در انجام وظايف و نقشهاى اجتماعى به دليل استمرار درد همراه با احساس عدم كنترل بر درد منجر به بيدايش علائم جندوجهى درد در بيماران مبتلا به درد مزمن مى گردد. از آن جايى كه هدف آموزش كمككهاى روانشناختى اوليه كمك به بيماران براى اكتساب مهارتهاى هدون مقابلهاى كارامل و دست يابى به برداشت منطقى از درد و نيز درك درستى از توانايىشان در كنترل درد است، نقش سودمندى در درمان بيامدهاى منفى و علائم جندوجهى درد خواهد داشت. نتايج به دست آمده در بررسى فرضيه دوم نشان داد كه

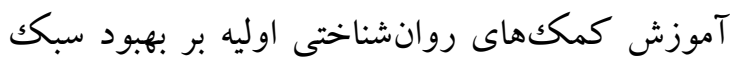
مقابلهاى مسئله مدار استرس در زنان مبتلا به اماس تأثير

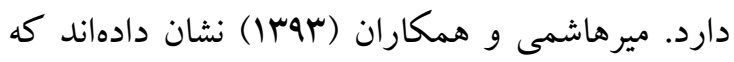

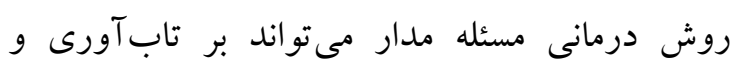
احساس انسجام بيماران مبتلا به اماس اثربخش باشد كه

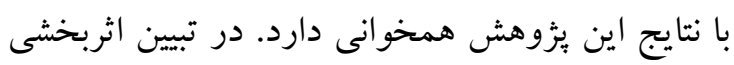

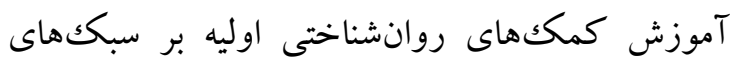




\section{Reference}

Afsari, Mohsen. (2010). Stress coping strategies in professional athletes. Master's Thesis. University of Sistan and Baluchestan. [In Persian].

Good news, Mohammad Ali, Barati, Nazanin. And Lotfi, Jamshid. (2008). The Relationship between Stress Coping Styles and Psychological Adaptation Levels in Patients with Multiple Sclerosis, Research in Medicine, 32, 1, 35-27. [In Persian].

Kerry, Gerald. (1394). Theory and Practice of Counseling and Psychotherapy, Seyed Mohammadi, Yahya, Arasbaran Publishing. [n Persian].

Latifi, Mani. (1390). MS in Human Language, Hirmand Publishing. [In Persian].

Lazarus, R. S. \& Folkman, S. (1984). stress Appraisal and coping, New York. Springer.

Lazarus, R. S. (1991). Emotional and adaptation. New York: Oxford University Press

Prochaska, James and Light Cross, John. (1393). Psychotherapy Theories (Psychotherapy Systems), Seyyed Mohammadi, Yahya, Psychoanalysis. [In Persian].

Rahimian Booger, Isaac. (2011). The Effect of Cognitive-Behavioral Therapy on Improving Multiple Pain Symptoms in Patients with Chronic Low Back Pain; Four Months Follow-up, Journal of Army University of Medical Sciences, 3, 199-208. [In Persian].

Soleani, Faezeh, Asghari Ebrahimabad, Mohammad Javad, Mashhadi, Ali., Attarzadeh Hosseini, Sayed Reza, Ahmadzadeh Ghavidl, Reyhaneh. And Mashhadinezhad, Hossein .(2012). The Effectiveness of Cognitive SelfManagement Program on Reducing Aggression and Multifocal Pain Symptoms in Chronic Pain, Journal of Anesthesiology and Pain, 7, 3, 38. [n Persian].

Turk, D. C.; Meichenbaum, D.; \& Genest, M. (1983). Pain and behavioural medicine. A cognitivebehavioural perspective. New York: The Guilford Press.

Turk, D.C \& Monarch E.S, (2012). Biopsych Perspective on chronic pui .In: DC, Turk and RJ, Eatchel, eds, psychological
درماندگى در بيماران اماس مطابقت مى كند و سبك مقابله هيجان مدار منفى با كاهش بهزيستى روانشناختى و افزايش درماندگى در بيماران اماس همراه است. يافتهاى يزوهشى نشان دادهاند كه سبك مقابله هيجان مدار با ويز گى جلب" حمايت عاطفى و اجتماعى " فرد را در مقابله با استرس تقويت مى كند و تقريباً همـواره

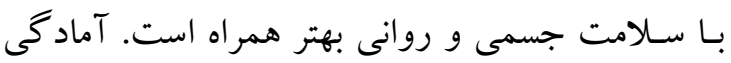
بيمار مبـتلا بـه اماس براى جستجوى حمايت اجتماعى بر اساس سبكك مقابله هيجان مدار مىتواند سطح

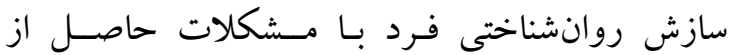
بيمـارى را افـزايش دهــــ. " توانايى تعبير و تفسير مجدد و مثبت" يكى از ويز گیىهاى سبك مقابله

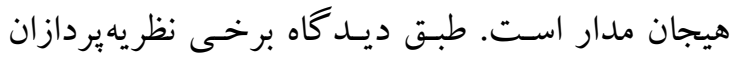

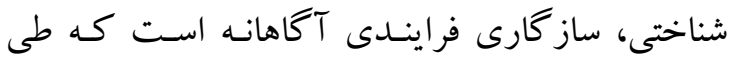
آن فرد ابتدا به ارزيابى مشكل بر اساس تجربههاى

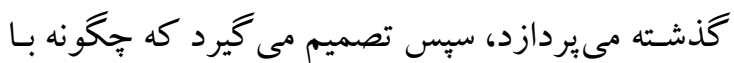
مشكل بيش آمده مقابله كند. بنابر اين، جّكونكى مقابله فرد با مـشكل بـه ارزيابى او از موقعيت بيش آمده

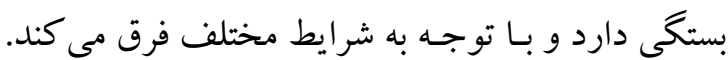

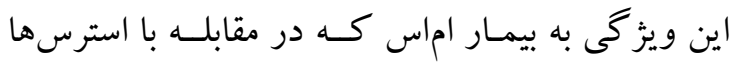

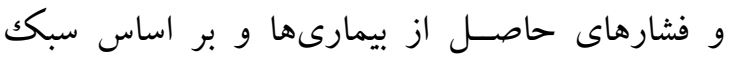
هيجان مدار مقابله مى كند، ايـن تـوان را مىدهد كه ارزيابى او از اين وضعيت بـالينى استرسزا مثبـت باشد. ارزيابى مثبت بيمار نيز به نوبه خود مىتواند بـر سـازش

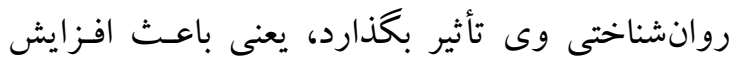

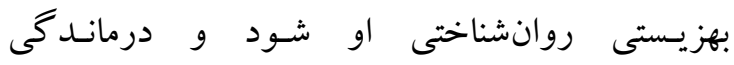
روانشناختىاش را كاهش دهد. با توجه به اينكه آموزش كمككهاى روانشناختى اوليه بر بيشتر خرده مقياسهاى بهبود علائم جند وجهى درد تأثير داشته، ييشنهاد مىشود كه اين آموزش به بيماران مبتلا به

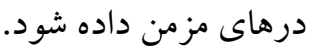


approachesto pain Management, Second edition new.3-29. York: Guilford.

Turk, D.C, Melzak R. (2001). The measurement of pain and the assessement of peaple experiencing pain: Handbook of pain assessment, 3.11. newYork: Guilford press.

Turk, D.c., Meichenbaum, D., \& Genest, M. (2013). Pain and behavioral medicine: A cognitive behavioral perspective. New York : Guilford press.

Turk, D.C., Son arch, E.S. (2006). Chronic Pain in P. Kennedy, Llewellyn (ED), The Essentials of Clinica Health Psychology .111-134.

Woolfolk, A. (1987), Educational psychology (3rd ed.). Englewood Cliffs, NJ: Prentice-Hall (640). 